\title{
Wind - Hydro Coordination for Enhanced Worth of Wind Power and Potentials in Karnataka State of India
}

\author{
Shravankumar Nayak, D.R Joshi
}

\begin{abstract}
The augmented demand for the power across the globe has resulted in the growth of non-conventional sources of energy as an appendage to the conventional sources. The large scale grid connected wind power systems have become one of the better alternatives among renewable energy based power generation methods. However the intermittency of wind power is one of the major limitations in the effective harvesting of energy leading to its reduced worth. Several methods are proposed and implemented to overcome the issue of wind power intermittency. In this paper a coordinated approach between wind and dispatchable and geographically proximal hydro power station is proposed to enhance the value of wind power. A MATLAB SIMULINK model of a wind power station is developed. Three potential sites with the conducive operating conditions for the implementation of the proposed scheme have been considered for the analysis. The results obtained are correlated to the enhanced worth of wind power.
\end{abstract}

Keywords: groundwater fluctuation, hydrologic parameter, infiltration, rainfall-runoff.

\section{INTRODUCTION}

The wind and solar power generations are the two prominent methods of bulk power generation after the recent shift in the paradigm of power generation from conventional to non-conventional methods. In India, the ample and unrestricted wind input, pollution less power generation, technological novelties and support from both central and various state governments have made the apprehensive stakeholders to offer the wind power generation as one of the major nonconventional mass power generation sources.

The Republic of India is located in Asia on the geographic coordinates of $210 \mathrm{~N}$ latitude and $780 \mathrm{E}$ longitude. India has remarkable potential of generating wind energy due to its geographical and a long coastal belt with favorable wind conditions. India stands fourth across the globe in the harvesting of energy from wind with an installed capacity of about $32746.87 \mathrm{GW}$ as per the latest data. The wind power potential of about $1,02,788 \mathrm{MW}$ has been estimated with the wind site having the power density greater than $200 \mathrm{~W} / \mathrm{sq} . \mathrm{m}$ at a hub height of $80 \mathrm{~m}$. The capacity addition of about $5.5 \mathrm{GW}$ has taken place in the year 2016-17[1]. The present wind power installed capacity in the country is around $32.5 \mathrm{GW}$ which is nearly 55 percent of the total renewable installed power generation capacity India added nearly $5.5 \mathrm{GW}$ of

Revised Version Manuscript Received on July 18, 2019.

Shravankumar Nayak, Electrical and Electronics Engineering Department SDM College of Engineering and Technology, Dharwad, India.

Dr.D. R. Joshi, Electrical and Electronics Engineering Department, Gogte Institute of Technology, Belagavi, India. wind power .

The central government has set an ambitious target of 175 GW of renewable power capacity by 2022 of which $60 \mathrm{GW}$ will come from wind. As a result of technological novelties, several hybrid projects are being proposed involving wind and solar and other dispatchable generation sources for the bulk power generation in addition to the conventional wind turbines.

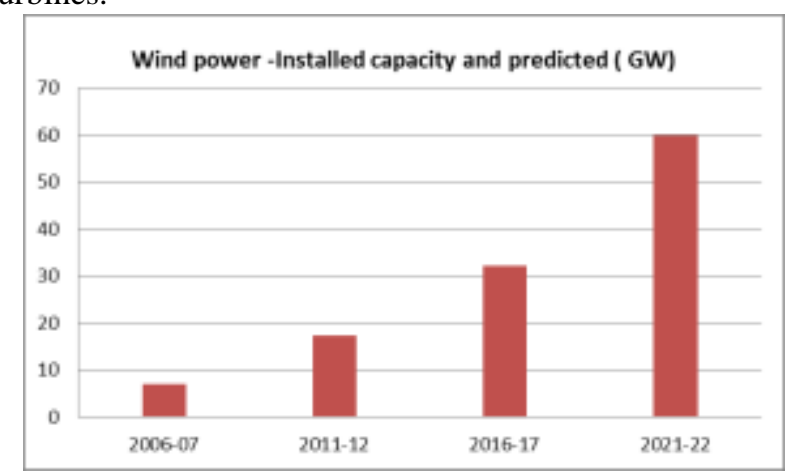

Fig. 1. Wind power installed capacity in India and projections.

The Fig 1. Shows the growth in the installed capacities of wind power and its projection for the year 2021-22.The state of Karnataka is located in the southern part of India and is one of the pioneer states in the effective harvesting of renewable energy. The state stands 4th in the country in the harvesting of wind power with an installed capacity of $4689.26 \mathrm{MW}$ up to June 2018[2].The wind power potentials in Karnataka based on wind speed is quite encouraging for the long term plans of wind power installations [3].

With increasing contribution of renewable energy sources, particularly wind, the reliability of the electric power system has to face the problem of balancing not only the power consumption but also the power generation. The variability in the wind speed which is nature dependent, hence the output power, further adds to the existing problems. The consequences of variability of wind power have made wind power non dispatchable, resulting in the reduced worth of wind power. Several proposals are made by various researchers to address the issue of non dispatchability of wind power. A comprehensive review of wind power dispatchability issues and enhancement methods is done by Shravankumar Nayak et.al [4].The different methods

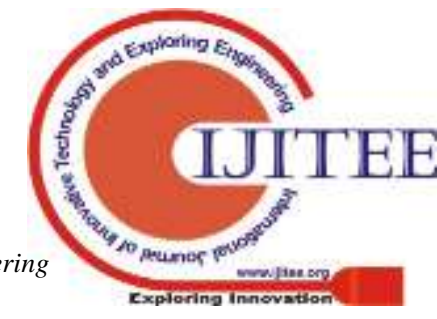




\section{WIND - HYDRO COORDINATION FOR ENHANCED WORTH OF WIND POWER AND POTENTIALS IN KARNATAKA STATE OF INDIA}

suggested by various researchers are suitable in specific operating conditions. There are no generic solutions to enhance the worth of wind power. Besides the solution is not always to build up a back-up system as suggested by many authors [5,6,7] but rather to make use of the existing dispatchable sources in required manner depending on the geographical conditions.

Wind power being non dispatchable and hence having reduced worth can be coordinated with other dispatchable sources of energy in a specific manner for its enhanced worth. The proposed methodology in this paper takes in to account the coordinated operation of wind power station, and a geographically proximal hydro power station which is considered to be one of the better dispatchable energy sources, using a suitable control strategy. As the results of reforms in the power sector and due to the strict guidelines in the form of grid codes, the power production profile has changed in India in the recent times. Pooling the power to the grids during the periods of less demand is likely to attract the penalties. Hence the power producing agencies strategically utilize the power produced during less demand period for storing the energy instead of shutting down the plants which becomes technically and economically unfeasible. In view of this strategy, the Government of Karnataka and Karnataka Power Corporation Limited (KPCL) have come up with a proposal of a pumped hydro power plant of 2000 MW capacity with an estimated investment of Rs.5017 Crores [8]. There have been several similar proposals in this regard by many researchers. For example, hybrid Pumped Hydro Storage plants that depend on wind power for frequent pumping have been proposed as economically feasible solutions for different geographic locations $[9,10]$. These proposals have their relevance for the customized systems developed. The present proposal though resembles the pumped hydro systems in structure [11], but the operation of the system is aimed at the enhancement of the worth of inconsistent wind power by means of its indirect storage.

The section 2 of this paper explains about the proposed scheme for the wind hydro coordinated operation. Section 3 describes about the modeling of a wind power station with required specifications. Section 4 discusses about the control strategy and three cases considered suitable for such coordinated operation with results, including economic considerations.

\section{PROPOSED SCHEME FOR WIND HYDRO COORDINATION}

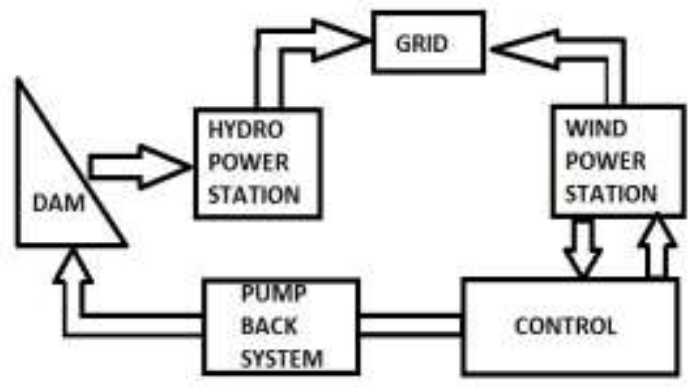

Fig. 2. Proposed scheme for wind hydro coordination
The Fig. 2 shows the block diagram of the proposed scheme of coordinated wind and a geographically proximal hydro power station. In this proposed method, a definite amount of wind power from the harvestable power depending on the site specific conditions is used to pump the water back to the dam from the tailrace storage using a suitable pumping system. This process is continued in a cumulative manner depending on the availability of wind power .Thus the coordinated operation cumulatively increases water level in the dam for the considered time period. The excess power from the wind power station is supplied to the grid. The geographical proximity between the two power stations makes the system more effective. Else, the transmission losses between the two coordinated power stations need to be accounted for. The complete implementation of wind hydro coordination (WHC) includes the following.

i) Wind power availability calculation

ii) Hydro power profile assessment and

iii) Development of a suitable control strategy for coordinated operation.

\section{A. Wind turbine model}

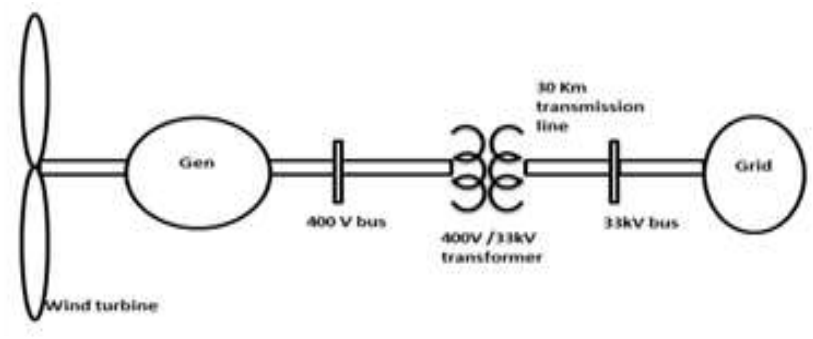

Fig. 3.1. Schematic diagram of grid connected wind turbine-generator system

In order to illustrate the wind hydro coordination control strategy, the wind turbine SIMULINK model has been developed by considering a synchronous generator based wind turbine connected to a grid. The schematic diagram of a synchronous generator based wind power station connected to a grid (a constant voltage source in the modelling) at a certain distance is shown in Fig 3.1. This model is validated by considering a real time site specific wind power station with the actual wind speed. [12].

\section{B. Hydro power profile assessment}

Hydro power stations are considered to be one of the best dispatchable energy sources because of their ability of quick turning on and meet the power obligation of the grid .In wind hydro coordination method, since it is required to pump back the water to the dam as a result of excessive wind power generation with respect to the set threshold value, the effective head of the dam, energy content of the dam (usually expressed as Million Cubic Feet of water required to produce million units of energy, MCFT/MU), power ratings of the pumps and the tailrace options are required to be precisely known. If the two power stations are located away from each other, then the transmission losses need to be considered. 
However in this proposed method, for the sake of convenience the transmission losses are neglected which assumes the nearness between the two power stations. In this study the similar cases have been considered for the analysis.

\section{Control strategy for the coordinated operation}

In the wind hydro coordination method, the dam functions as the backup storage for the wind energy within the limitations as posed by the wind profile of the area, pumping efficiency and availability of tailrace storage. The cumulative pumping back of water for a considered period of time enhances the water level in the dam compared to the conventional operation of hydro power station. This surplus water which is the definite potential energy due to the inconsistent kinetic energy of the wind can be used during the periods of acute shortage of energy especially in the summer months. This proposal is expected to augment the worth of wind power as a result of its ancillary storage. The control strategy for wind hydro coordination should address the contemplations of the output of the wind power station for the considered period, the energy requirement for the pumping system which can be tenaciously decided to be certain constant percentage of generated wind power and status of the water volume in the dam. The power required to pump back the water is calculated using a general power equation for pumping given by

$$
\begin{array}{cl}
P=(Q H g \rho) / \eta & \\
\text { where } & \mathrm{H}=\text { Head in meters } \\
& \text { Q=Discharge in } \mathrm{m}^{3} / \mathrm{sec} \\
& \rho=\text { Density in } \mathrm{Kg} / \mathrm{m}^{3} \\
& \mathrm{~g}=\text { Gravity constant } \mathrm{m} / \mathrm{s}^{2} \text { and } \\
& \eta=\text { Overall pumping efficiency }
\end{array}
$$

\section{Flowchart of control operation}

For Ns=700 hours (Number of pumping hours in each month)

$$
\begin{aligned}
& \rho=1000 \mathrm{Kg} / \mathrm{m}^{3} \text { for water } \\
& g=9.81 \mathrm{~m} / \mathrm{sec}^{2} \\
& \eta=70 \% . \text { (Assumed) }
\end{aligned}
$$

Then the pump back constant Pc which is used to convert discharge in $\mathrm{m}^{3} / \mathrm{sec}$ to TMC (Thousand Million Cubic Feet) for one month is calculated as

$$
\text { Pc=9.33e-6 }
$$

The following flowchart describes the control strategy of the coordinated operation.

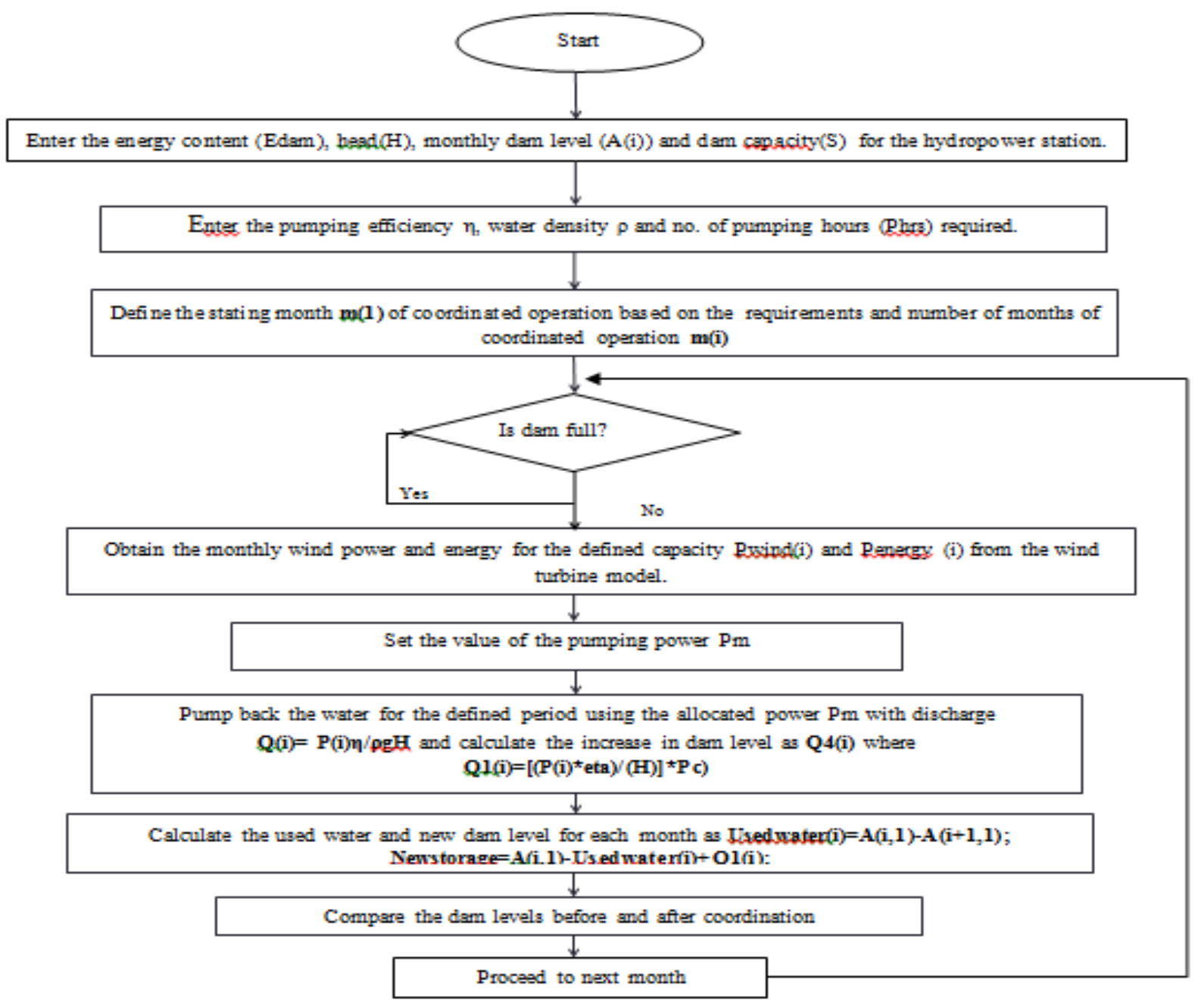

Fig. 3.d. Flowchart for the implementation of control strategy 


\section{WIND - HYDRO COORDINATION FOR ENHANCED WORTH OF WIND POWER AND POTENTIALS IN KARNATAKA STATE OF INDIA}

Table I: Details of the hydropower stations considered

\begin{tabular}{|c|c|c|c|c|c|c|}
\hline Name & $\begin{array}{c}\text { Location and year of } \\
\text { commissioning }\end{array}$ & Dam capacity & $\begin{array}{c}\text { Power station } \\
\text { capacity }\end{array}$ & $\begin{array}{c}\text { Designed } \\
\text { energy capacity }\end{array}$ & $\begin{array}{c}\text { Type of } \\
\text { turbine, Head }\end{array}$ & Energy content \\
\hline $\begin{array}{l}\text { Almatti Dam } \\
\text { Power House }\end{array}$ & Almatti, Bagalkot, 2005 & $\begin{array}{c}124 \mathrm{TMC} / \\
124000 \mathrm{MCFT}\end{array}$ & $290 \mathrm{MW}$ & $719 \mathrm{MU}$ & $\begin{array}{c}\text { Vertical } \\
\text { Kaplan, } 25 \mathrm{~m}\end{array}$ & $520 \mathrm{MCFT} / \mathrm{MU}$ \\
\hline $\begin{array}{l}\text { Hidkal Dam } \\
\text { Power house }\end{array}$ & $\begin{array}{c}\text { Hidkal,Chikkodi, } \\
1977\end{array}$ & $\begin{array}{c}48 \mathrm{TMC} / \\
48000 \\
\text { MCFT }\end{array}$ & $32 \mathrm{MW}$ & $97.56 \mathrm{MU}$ & $\begin{array}{c}\text { Vertical } \\
\text { Kaplan, } 32 \mathrm{~m}\end{array}$ & $492 \mathrm{MCFT} / \mathrm{MU}$ \\
\hline $\begin{array}{c}\text { Bhadra Dam } \\
\text { Power House. }\end{array}$ & $\begin{array}{c}\text { Tarikere, } \\
\text { Chikmaglur, } \\
1965\end{array}$ & $71.5 \mathrm{TMC}$ & $39.2 \mathrm{MW}$ & $84 \mathrm{MU}$ & $\begin{array}{c}\text { Vertical } \\
\text { Kaplan, } 42 \mathrm{~m}\end{array}$ & $860 \mathrm{MCFT} / \mathrm{MU}$ \\
\hline
\end{tabular}

The wind hydro coordination method is site specific with favourable conditions for the operation. The region where this proposal can be effectively implemented should have fairly good wind conditions for the effective harvesting of wind energy and a proximate hydro power station. The implementation methodology and cost depend on the ratings of each power stations considered. For the proposed implementation of the control strategy, three such sites are identified in the state of Karnataka in India and the analysis has been done. In India, Monsoon usually begins in the mid-June and continues up to September. Hence in the south west part of the country, the dams get filled up in the months of July or August as per the statistics. Therefore pumping back process cannot be started earlier to September. The steady consumption of water can be observed once the storage due to Monsoon stops and an almost linear reduction in the water volume can be observed as a function of time till the new season starts or the water level reaches a minimum value (dead storage) whichever is earlier. Thus in the proposed system the coordinated operation is chosen to begin in the month of December and continues till May for a period of six months in each year. After the implementation of the control strategy the dam water volume in the month of May which is the mid-summer where shortage of electrical power is likely to be experienced, is compared with the storage in the dam under normal circumstances. The following three cases have been considered in this analysis.

\section{A. Almatti Dam Hydropower Station:}

Almatti Dam Power House (ADPH) is one of the hydro power projects of the Karnataka Power Corporation Limited (KPCL) located in the north central part of Karnataka. The wind power potential in and around ADPH is quite encouraging with an annual mean wind speed of about $5 \mathrm{~m} / \mathrm{s}$. Several private power producers have already commissioned wind power plants in this area. Hence this site is well thought-out for the implementation of the proposed methodology.

\section{B. Hidkal Dam Hydropower Station:}

The Hidkal Dam Power House(HDPH), in the Chikkodi district of north Karnataka in India is located at the head works of the Ghataprabha multipurpose Dam on the right bank of the river with an installed capacity of $32 \mathrm{MW}$ and an

\section{CASE STUDIES OF PROPOSED IMPLEMENTATION \& RESULTS}

expected annual energy yield of 131MU. The wind profile around the power house is very encouraging with several private wind power plants are already in operation.

\section{Bhadra Dam Hydropower Station:}

The Bhadra Dam Power House (BDPH) is located in Tarikere of Chickmagalur district of south interior Karnataka with a storage capacity of $71.5 \mathrm{TMC}$. There are three different power houses with capacities of 26, 7.6 and $6 \mathrm{MW}$ each with the total capacity of 39.6 MW and a designed energy yield of approximately $83 \mathrm{MU}$. The detailed specifications of all the three power station are shown in table I.

For the coordinated operation of wind and hydro power stations, a wind power station of approximately $10 \%$ of the hydro power station rating is considered in the present analysis for convenience. After the implementation of the control strategy for the considered rating of the wind power station and the actual hydro power station the following results are obtained.

1.Estimated harvestable power and energy for one year based on the real time wind speed obtained from competent authorities.

2.For the hydro power station the enhanced water volume in the dam as the indirect storage of wind energy.

3.The grid fed wind energy in excess of the energy required for pump back.

The table II shows the estimated harvestable energy for the three sites considered with their respective rating.

Table II: Estimated harvestable energy from wind power stations

\begin{tabular}{|l|c|c|c|}
\hline \multirow{2}{*}{ Month } & \multicolumn{3}{|c|}{ Average monthly harvestable power in MW } \\
\cline { 2 - 4 } & $\begin{array}{c}\text { Almatti } \\
(30 \mathrm{MW})\end{array}$ & $\begin{array}{c}\text { Ghataprabha } \\
(4.5 \mathrm{MW})\end{array}$ & $\begin{array}{c}\text { Tarikere } \\
(3 \mathrm{MW})\end{array}$ \\
\hline June-2017 & 30 & 3.04 & 2.08 \\
\hline July & 26.9 & 2.83 & 1.94 \\
\hline August & 16.8 & 1.26 & 1.01 \\
\hline September & 8.35 & 0.79 & 0.50 \\
\hline October & 8.04 & 0.608 & 0.35 \\
\hline November & 6.76 & 1.144 & 0.488 \\
\hline December & 6.21 & 0.647 & 0.496 \\
\hline January -18 & 9.09 & 0.597 & 0.991 \\
\hline February & 6.28 & 0.839 & 0.529 \\
\hline March & 8.46 & 0.831 & 0.078 \\
\hline April & 12.98 & 1.51 & 0.747 \\
\hline May & 20.49 & 2.98 & 1.995 \\
\hline
\end{tabular}


Table III: Water storage comparison before and after WHC

\begin{tabular}{|c|c|c|c|c|c|c|}
\hline \multirow[b]{3}{*}{ June- 2017} & \multicolumn{6}{|c|}{ Water storage comparison before and after WHC } \\
\hline & \multicolumn{2}{|c|}{$\begin{array}{c}\text { Almatti Dam } \\
\text { (124 TMC) }\end{array}$} & \multicolumn{2}{|c|}{$\begin{array}{c}\text { Ghataprabha Dam } \\
\text { (48 TMC) }\end{array}$} & \multicolumn{2}{|c|}{$\begin{array}{c}\text { Tarikere Dam } \\
\text { (71.5 TMC) }\end{array}$} \\
\hline & 9.93 & - & 6.65 & - & 8.73 & - \\
\hline July & 16.22 & - & 30.89 & - & 15.56 & - \\
\hline August & 123.61 & - & 31.92 & - & 28.87 & - \\
\hline September & 122.83 & - & 43.24 & - & 43.38 & - \\
\hline October & 123.08 & - & 46.34 & - & 50.31 & - \\
\hline November & 123.08 & - & 41.14 & - & 54.87 & - \\
\hline December & 98.88 & 100.50 & 35.60 & 35.72 & 53.20 & 53.27 \\
\hline January -2018 & 78.38 & 81.62 & 26.40 & 26.64 & 52.98 & 53.13 \\
\hline February & 57.73 & 62.59 & 16.50 & 16.86 & 43.28 & 43.51 \\
\hline March & 43.68 & 50.16 & 13.54 & 14.02 & 34.05 & 34.77 \\
\hline April & 24.47 & 32.57 & 8.06 & 6.67 & 23.02 & 23.432 \\
\hline May & 22.97 & 32.69 & 6.30 & 7.03 & 14.05 & 14.43 \\
\hline $\begin{array}{l}\text { Intermittent approximate energy from } \\
\text { wind for six months(Dec-May) without } \\
\text { WHC }\end{array}$ & \multicolumn{2}{|c|}{$46.23 \mathrm{MU}$} & \multicolumn{2}{|c|}{$5.39 \mathrm{MU}$} & \multicolumn{2}{|c|}{$3.52 \mathrm{MU}$} \\
\hline $\begin{array}{l}\text { Net definite energy available after } \\
\text { WHC(May) } \\
\text { (Enhanced worth of wind power) }\end{array}$ & \multicolumn{2}{|c|}{$18.69 \mathrm{MU}$} & \multicolumn{2}{|c|}{$1.48 \mathrm{MU}$} & \multicolumn{2}{|c|}{$0.487 \mathrm{MU}$} \\
\hline
\end{tabular}

The table III shows the comparison of water level in the three dams considered in the study, before and after WHC for the considered time period. The statistics of actual storage of water in the dam are obtained from concerned authorities [13] It should be noted that based on the water storage conditions of the dams the WHC strategy is applied starting from the month of December for successive six months. The comparison of the results is done in the month of May. The net definite energy available in the form of dispatchable hydro energy in the month of May is 18.69MU, 5.39 MU and 0.487 MU respectively for the three cases considered.

The table IV shows the grid fed wind power form the three wind power stations considered in this study. This power is in excess of the wind power used for pumping the water back to the dam due to its excessive availability.

\section{Table IV: Grid fed energy from wind power station}

\begin{tabular}{|l|c|c|c|}
\hline \multirow{2}{*}{ Month } & \multicolumn{3}{|c|}{ Grid fed wind power } \\
\cline { 2 - 4 } & Almatti & Ghataprabha & Tarikere \\
\hline June- 2017 & 30.0 & 3.04 & 2.08 \\
\hline July & 26.9 & 2.83 & 1.94 \\
\hline August & 16.8 & 1.26 & 1.01 \\
\hline September & 8.35 & 0.79 & 0.50 \\
\hline October & 8.04 & 0.608 & 0.35 \\
\hline November & 6.76 & 1.144 & 0.488 \\
\hline December & 0 & 0.05 & 0 \\
\hline January 2018 & 2.88 & 0 & 0.495 \\
\hline February & 0.07 & 0.242 & 0.033 \\
\hline March & 2.25 & 0.234 & 0.078 \\
\hline April & 6.77 & 0.913 & 0.251 \\
\hline May & 14.28 & 2.38 & 1.499 \\
\hline $\begin{array}{l}\text { Total Energy } \\
\text { in MU }\end{array}$ & 89.79 & 9.84 & 6.36 \\
\hline
\end{tabular}

The figure 4.a shows the comparison of the installed capacity of each wind power station and their respective grid fed wind energy and equivalent values in the form of additional water stored in dams. This is vital information needed for the economic feasibility analysis of the proposed method.
The figure 4.b shows the comparison of water volume and stored equivalent wind energy in the form of water in the each dam considered in this study for a pumping efficiency of $70 \%$. However these values may differ for different conditions.

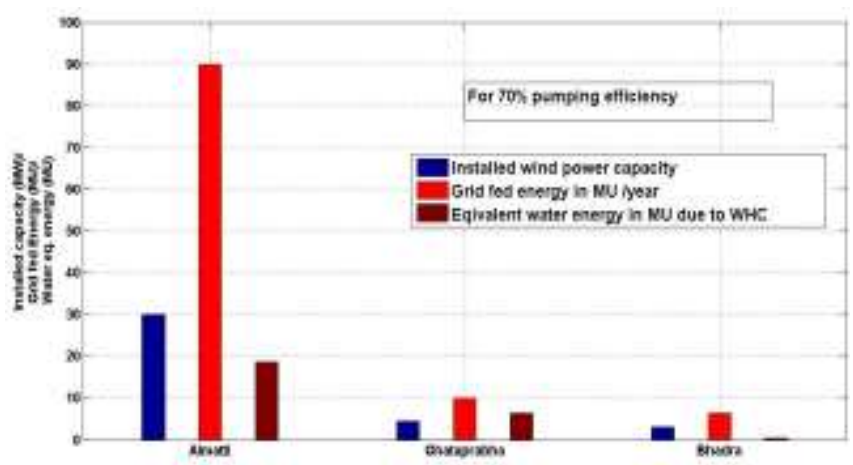

Fig. 4. a. Comparison of the installed capacity of each wind power and their respective grid fed wind energy and equivalent energy stored as water

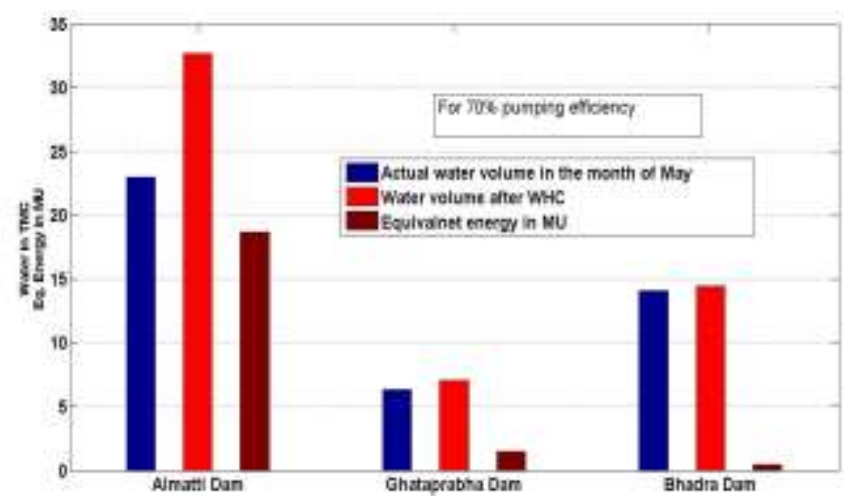

4.b. Comparison of water volume in the month of Mat before and after WHC and corresponding equivalent energy. 


\section{WIND - HYDRO COORDINATION FOR ENHANCED WORTH OF WIND POWER AND POTENTIALS IN KARNATAKA STATE OF INDIA}

The table $\mathrm{V}$ shows the comparison of the performance of wind hydro coordination of the three sites considered in this study based on the data of one water year (June 2017- May 2018)

Table V. Performance comparison of the three considered sites

\begin{tabular}{|l|c|c|c|}
\hline \multicolumn{1}{|c|}{ Parameters } & \multicolumn{3}{|c|}{ Sites considered } \\
\hline $\begin{array}{l}\text { Actual harvestable } \\
\text { wind energy (MU) }\end{array}$ & Almatti & Ghataprabha & Bhadra \\
\hline $\begin{array}{l}\text { Wind energy utilized } \\
\text { for pump back for six } \\
\text { months(MU) }\end{array}$ & 8.55 & 12.46 & 8.17 \\
\hline $\begin{array}{l}\text { Indirect definite energy } \\
\text { stored in the dam(MU) }\end{array}$ & 18.69 & 1.48 & 1.323 \\
\hline $\begin{array}{l}\text { Excess wind energy to } \\
\text { be supplied to the } \\
\text { grid(MU) }\end{array}$ & 89.79 & 9.84 & 6.36 \\
\hline $\begin{array}{l}\text { Utilization percentage } \\
\text { as definite energy }\end{array}$ & $68.60 \%$ & $56.48 \%$ & $27 \%$ \\
\hline
\end{tabular}

From the above table it can be observed that the approximate payback period for the first two sites is 4 years while for the third site it is about 6 years. This is due to the fact that a comparatively large amount of energy requirement for the pump back due to the higher value of the head. Eventually these figures for any specific site depend on the wind profile at that area, effective head of the dam, hydrology of the area and the provision of tailrace and the cost of energy assuming the other parameters to be constants.

It can be seen that, in Almatti site $68 \%$ wind energy deployed for pump back can be used as definite wind energy stored in the form of hydro energy. For the other two sites this value is $56.48 \%$ and $27 \%$ respectively.

\section{Economic analysis:}

The feasibility of this proposal is strongly correlated to the economic aspects involved. Since the proposal is analysed for the sites where the hydro power stations are already in operation, the cost for the hydropower station is excluded here. However the different costs that are involved for the wind for station and the associated additional costs are considered in the economic analysis. As per the present trend the cost per watt of wind power installation is taken as Rs.65 for Indian scenario [14]

The overall cost for pump back and the miscellaneous costs that include provision for tailrace storage and interest factors are considered to be about $25 \%$ of the wind system cost. The table VI illustrates the economic analysis for the three sites under consideration.

Table VI. Economic analysis of the three considered sites

\begin{tabular}{|c|c|c|c|c|c|c|c|c|}
\hline \multirow[b]{2}{*}{ Cases } & \multicolumn{2}{|c|}{ Energy } & \multicolumn{3}{|c|}{ Expenditure } & \multicolumn{3}{|c|}{ Revenue(yearly) } \\
\hline & $\begin{array}{c}\text { Grid } \\
\text { fed } \\
\text { wind } \\
\text { energy } \\
\text { Egrid } \\
\text { (MU) }\end{array}$ & $\begin{array}{c}\text { Energy } \\
\text { saved due } \\
\text { to pump } \\
\text { back } \\
\text { Epb } \\
\text { (MU) }\end{array}$ & $\begin{array}{c}\text { Wind } \\
\text { power } \\
\text { installation } \\
\text { cost } \\
\text { (Rs 65/W) } \\
C \boldsymbol{w} \\
\text { (Crores) }\end{array}$ & $\begin{array}{c}\text { Cost of pump } \\
\text { back } \\
(25 \% \text { of } \mathrm{CW}) \\
\text { (Rs 6.5/W) } \\
\boldsymbol{C p b} \\
\text { (Crores) }\end{array}$ & $\begin{array}{c}\text { Total } \\
\text { expenditure } \\
\boldsymbol{C t} \boldsymbol{t}=\boldsymbol{C w}+\boldsymbol{C p b} \\
\text { (Crores) }\end{array}$ & $\begin{array}{c}\text { Total grid fed } \\
\text { energy } \\
\text { revenue } \\
@ \text { Rs4/Kwh } \\
\boldsymbol{R g} f \boldsymbol{e} \\
\text { (Crores) }\end{array}$ & $\begin{array}{c}\text { Revenue due } \\
\text { to saved } \\
\text { energy } \\
\text { @ Rs7/Kwh } \\
\text { Rse } \\
\text { (Crores) }\end{array}$ & $\begin{array}{c}\text { Total } \\
\text { revenue } \\
\boldsymbol{R} \boldsymbol{t} \\
(\boldsymbol{R g} \boldsymbol{f} \boldsymbol{e}+\boldsymbol{R} \boldsymbol{s} \boldsymbol{e}) \\
\text { (Crores) }\end{array}$ \\
\hline Almatti & 117.03 & 18.69 & 195 & 48.75 & 243.75 & 46.81 & 13.08 & 59.89 \\
\hline Ghataprabha & 12.46 & 1.48 & 29.25 & 7.31 & 36.56 & 4.98 & 1.036 & 6.02 \\
\hline Bhadra & 8.17 & 0.487 & 19.5 & 4.88 & 24.36 & 3.26 & 0.340 & 3.60 \\
\hline
\end{tabular}

\section{CONCLUSION}

The objective of this proposal is to make the effective utilization of wind power in the prevailing scenario. Hence the present method proposes the wind hydro coordination strategy subjected to the conducive geographical wind and hydro power stations where the intermittent wind power is utilized to pump the water back to the dam by appropriately rated pumps for the cumulative increases in the dam storage. This indirect wind energy can be utilized during the summer peak demand periods or some unexpected drought conditions with reduced dam levels. The power cannot be produced at the will of the power producers due to strictly imposed grid codes. Hence the off peak power production can always be thought of for pumping back activity of released water from the dam instead of shutting down the power plants which is technically difficult in many cases. The present proposal is a supplementary proposal with a decentralized system and reduced rating and cost of the system aiming only at the existing sites to enhance of the worth of wind power.
Depending on the topology of the sites the precise economic analysis can be further made to identify the suitability of such schemes in various regions. The generic method developed can be effectively used to evaluate the possible definite energy available from a wind power station which is not possible in its routine conventional operation.

\section{ACKNOWLEDGEMENT}

The authors would like to thank The Karnataka Power Corporation Limited, Karnataka (KPCL), and Water Resource Information System, National Remote Sensing Centre (NRSC), Government of India and Ministry of New and Renewable Energy, Government of India for their valuable data. 


\section{REFERENCES}

1. Ministry of New and Renewable Energy, Press Information Bureau Government of India 27- December-2017.

2. Karnataka Renewable Energy corporation Limited, Project allotted status available http://kredlinfo.in/wind/Allotted_status.pdf

3. T.V. Ramachandra, B.V. Shruthi, "Wind Energy Potential Mapping in Karnataka, India, using GIS," Energy Conversion and Management, Volume 46, Issues 9-10, 2005, Pages 1561-1578, ISSN 0196-8904

4. Nayak Shravankumar, Joshi Diwakar, "Wind power dispatchability issues and enhancement methods-A review," IEEE International Conference on Circuit, Power and Computing Technologies (ICCPCT), pp.1,7, 19-20 March 2015.

5. H Ibrahim,M Ghandour, $M$ Dimitrova, A. Ilinca, J.Perron,"Integration of wind energy into electricity systems: Technical challenges and actual solutions", Elsevier Energy Procedia 2011.

6. Li Jianlin, Liang Liang, Yangshuili, Hui Dong," Study on Energy storage system smoothing wind power fluctuations", International Conference on Power System Technology IEEE 2010

7. W Z Chen, Q B Lee, "Energy storage sizing for dispatchability of wind form", 11th International Conference on Environment and Electrical Engineering EEEIC, 2012

8. Sharavathy Pumped Storage Project(2000 MW), Prefeasibility report, April 2017 available at environmentclearance.nic.in/.../13_Jun_2017_15012044 7HIN21JHA Prefeasibility Report

9. Tyhly: A. Tuohy, M. ОГÇÖMalley, Pumped storage in systems with very high wind penetration, Energy Policy, Volume 39, Issue 4, 2011, Pages 1965-1974, ISSN 0301-4215.

10. Bahtiyar Dursun, Bora Alboyaci, The contribution of wind-hydro pumped storage systems in meeting Turkey's electric energy demand, Renewable and Sustainable Energy Reviews, Volume 14, Issue 7, 2010, Pages 1979-1988, ISSN 1364-0321

11. Shravankumar Nayak, D R Joshi, V R Sheelavant, Performance Analysis of Grid Connected Wind Turbine Generators on the Basis of Energy Harvesting - A Case Study, International Journal of Advanced Research Trends in Engineering and Technology (IJARTET) Vol. 4 Issue 6, June 2017

12. Water resource Information System, National Remote Sensing Centre (NRSC), Government of India, available at https://india-wris.nrsc.gov.in

13. V. Neimane,"Collaboration between Wind Power and Hydro power", Vattenfall Utveckling AB, Report No. U03:78, Stockholm, 2003.

14. The Power to Change: Solar and Wind Cost Reduction Potential to 2025 (Abu Dhabi: 2017), http://www.irena.org/DocumentDownloads/Publications/ IRENA_Power_to_Change_2016.pdf.

\section{AUTHORS PROFILE}

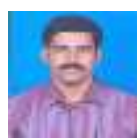

Shravankumar Nayak obtained his B. E from SDM College of Engineering and Technology Dharwad, India and M.Tech from BVB College of Engineering and Technology, Hubballi, India and currently persuing his Ph.D from Visveswaraya Technological University, Belagavi,India. He has 4 international Journal publications and presented more than 10 papers in international/national conference. His reserch area of interest are Renewable Integration and FACTS controllers.

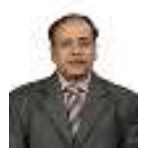

Dr. D R Joshi obtained his BE and ME degrees form Karnataka University and Mysore University respectively and obtained his $\mathrm{Ph}$. D from Visveswaraya

Technological

University,Belagavi,India in 2010. He has about 25 international publications and attended several International and National conferences. Presently he is working as the Professor and Head of Electrical Engineering Department of Gogte Institute of Technology, Belagavi, India. His research areas of interest are Renewable Energy Sources, Power System Planning and ANN application to Power System. 